\title{
ЦЭЭНИЙН ТӨРЛИЙН УРГАМАЛ ДАХЬ ГОЛ НЭГДЛУУД
}

\author{
Э.Пүрэвдорж, Г.Одонтуяа \\ Байгалийн нэгдлийн химийн лаборатори, Хими, химийн технологийн хүрээлэн, \\ Шинжлэх ухааны Академи, Монгол улс \\ Цахим шуудан: g.odontuya@hotmail.com
}

Редакиид ирүүлсэн: 2016.02.02

Товч агуулга: Бид монгол оронд ургадаг Цээнийн төрлийн Цагаан иээнэ (Paеопіа lactiflora Pall.) ба Ягаан иээнэ (Paeonia anomala L.)-н газрын дээд хэсэг, иэџฺэг, Үндэсний химийн бүрэлдэхүҮн, найрлагыг харьиуулан анх удаа судалж тэдгээрт квериетин (1), кемпферол (2), кемпферол-3-O- $\beta$-D-глюкопиранозид (3) этилгаллат (4), галлын хүчил (5), 1,2,3,4,6-пентагаллоил-O- $\beta$-D-глюкопираноз (6), паеонифлорин (7) зонхилдог болохыг тогтоолоо. Эдгээрээс нэгдэл 1-г Цагаан и̧ээнэ болон Ягаан иэээнэ, нэгдэл 3-г Ягаан иฺээнээс тус тус анх удаа ялгав.

Дээрх хоёр зүйл Цээнийн эмийн түүхий эдэд энгийн фенол (4, 5), таннин (6) болон монотерпений гликозид (7) харьцангуй их байгаа нь тэдгээрийг ялгаж, бүтэи байгууламжийг тодорхойлох явцад тогтоогдлоо. Харин флавоноидын уламжлальн нэгдэл нь $(1,2,3)$ бусад ангиллын нэгдлээс бага боловч газрын дээд хэсэгт зонхилж байна.

Цагаан иэээнийн газрын дээд хэсэгт нэгдэл 3 (0.108\%), 4 (0.216\%), 6 (0.165\%) их байгаa бол Ягаан иэээнийхэд 4 (0.361\%), 6 (0.386\%) and 7 (0.725\%) зонхилж их хэмжээтэй байна. Мөн эдгээр нэгдэл нь Ягаан иэээнийн иэигэнд их илэрч байв. Дээрх хоёр зүйл Цээнийн Үндсэнд флавоноидьцн төрлийн нэгдлүүд илрээгүй бол харин аль алинд нь нэгдэл 4, 7 мами их хэмжээтэй агуулагдаж байна.

Цээнийн төрлийн дээрх хоёр зүйлийн химийн бүрэлдэхүүн, найрлагьы харьиуулан судалсан ажил урьд өмнө байгаагүй тул тэдгээрт зонхилон агуулагддаг биологийн идэвхт нэгдлүүдийн тоо хэмжээг эмийн түҮхий эд тус бүрт нь анх тодорхойлсон нь иинжлэх ухааны шинэ мэдээлэл болж байна. Энэ нь эдгээр ургамльн ямар эд, эрхтэнг эм, хүнс, гоо сайхны бүтээгдэхүҮний түүхий эд болгон ашиглаж болохыг илэрхийлж буй үнэ иэнэтэй суурь мэдээлэл болохын зэрэгиээ практик ач холбогдолтой юм.

Түлхүур үг: Цагаан изээнэ, Ягаан иээнэ, биологийн идэвхт нэгдэл, молекульцн бүтэи, агууламж

\section{ОРШИЛ}

Цээнийн (Paeoniaceae) овгийн Цээнийн (Paeonia) төрлийн 35 зүйл ургамал өмнөд Америк, Евроази, зүүн өмнөд Азийн нутагт зонхилон ургадаг бол харин манай оронд Цагаан изэнэ (Paeonia lactiflora Pall.) ба Ягаан иээнэ (Paeonia anomala L.) хэмээх хоёр зүйл Монгол дагуур, Хянган, Дорнод монгол, Хөвсгөл, Хэнтийн нутагт ургадаг $[1,2]$.

Дорно дахины анагаах ухаанд Цагаан иээнийн (Ци) үндсийг өргөн хэрэглэж ирсэн уламжлалтай ба Хятадын уламжлалт эмийн 36 жорын найрлаганд орж, жорын найрлаганд орох давтамжаараа 10-т 
бичигддэг байна [3]. Уг ургамлын газар доорх хэсгийг бөөрний үйл ажиллагаа алдагдах, амьсгалын замын цочмог өвчнүүдийн үед, цусны даралт ихсэх, ходоодны өмөн хавдар, энцефалит, эмэгтэйчүүдийн өвчин, нүдний торлогт цус хурах, цус шингэлэх, ходоод гэдэсний үрэвсэлд болон тайвшруулах үйлдэлтэйгээр хэрэглэж ирсэн уламжлалтай [4].

Харин Ягаан цэээн (Яи) монголтөвөдийн анагаах ухааны эмийн 55 жоронд орж, жорын найрлаганд орох давтамжаараа 107-д бүртгэгджээ [3]. Дорно дахины анагаах ухаанд түүний үндэснээс бэлтгэсэн эмийг толгой эргэж нүд харанхуйлах, гар, хөл татах, гүйлгэх, цус багадах, сарын тэмдэг тогтмол ирэхгүй байх, шээс задгайрах, савнаас цус алдах зэрэг өвчний эмчилгээнд хэрэглэж ирсэн уламжлалтай [4].

Цээнийн төрлийн ургамлын химийн найрлага бүрэлдэхүүний судалгаа маш сайн хийгдсэн бөгөөд түүнд “тэрэг” хэлбэрийн монотерпен, монотерпений гликозид, фенолт нэгдэл флавоноид, таннин, энгийн фенолт нэгдлүүд зонхилдог ба эдгээр нь Цээнийн төрлийн ургамлын биолог, фармакологийн үйлдлийг нөхцөлдүүлдэг

\section{СУДАЛГААНЫ МАТЕРИАЛ, АРГА ЗУЙ}

\section{Ургамльнн түҮхий эдийг бэлтгэх}

Ци-н газрын дээд хэсэг (гдх) болон үндсийг 2009 оны 08-р сарын эхээр Хэнтий аймгийн Дадал сумын нутаг Цээнэтэй хэмээх газраас, Яи-н гдх-г 2009 оны 08-р сарын эхээр, үндсийг 2007 оны 07-р сард Булган аймгийн Могод сумаас, цэцгийг 2013 оны 6-р сард Төв аймгийн Жаргалант сумаас тус тус түүж, хатааж бэлтгэв. Ургамлын ангилал зүйн тодорхойлолтыг ШУА, Ерөнхий ба сорилын биологийн хүрээлэнгийн эрдэм шинжилгээний тэргүүлэх ажилтан, шинжлэх ухааны доктор Ч.Санчир хийсэн болно.
[5-7].

Фенолт нэгдэл нь ургамлын аймагт өргөн тархсан хоёрдогч метаболит бөгөөд одоогоор 8000 гаруй фенолт нэгдлийг ургамлаас ялгаж, молекулын бүтцийг тогтоогоод байна [8]. Фенолт нэгдлийг тэдгээрийн химийн бүтцээс нь хамааруулж энгийн фенол, фенол хүчил, флавоноид, кумарин, антрацен, ксантон, лигнан гэж ангилдаг ба эдгээр нь молекулын бүтэц байгууламжийн онцлогоосоо шалтгаалан харилцан адилгүй биологийн идэвхтэй байдаг [9]. Судлаачид фенолт нэгдлийн үл исэлдүүлэх, үрэвслийн эсрэг, дархлаа дэмжих, харшил дарах, цус бүлэгнэхээс сэргийлэх, вирусын эсрэг, нян бичил биетнийг устгах, хавдрын эсрэг зэрэг үйлдлийг судалж тогтоосон байна [10-11].

Бидний энэхүу судалгааны ажил нь монгол оронд ургадаг Цээнийн төрлийн дээрх хоёр зүйл ургамлын газрын дээд хэсэг, цэцэг, үндэс гэсэн эмийн түүхий эдийн химийн бүрэлдэхүүн, найрлагыг харьцуулан анх удаа судалж, тэдгээрт зонхилдог биологийн идэвхт нэгдлүүдийг ялгаж, молекулын бүтэц байгууламжийг тогтоож, түүхий эд бүрт агуулагдах хэмжээг тодорхойлсноороо онцлог юм.

Ургамльн түҮхий эдийг хандлах, бүлэглэн хандлах

Ци-н гдх, үндэсний тус бүр 1.0 кг, Яи-н гдХ-н 1.0 кг, үндэсний 5.8 кг, цэцгийн 1.5 кг агаарын хуурай хатаасан дээжийг $80 \%$ этилийн спиртээр тасалгааны температурт мацерацын аргаар хандалж этанолын ханд, түҮнээс дихлорметан (ДХМ), этилацетат (ЭА), $н$-бутанолын (n-BuOH) бүлэг хандыг тус тус гарган авч химийн судалгаанд бэлтгэв (Хүснэгт 1). 
Хуснэгт 1

Цээнийн төрлийн ургамльн түҮхий эдийн ханд ба бүлэг ханд

\begin{tabular}{|c|c|c|c|c|c|}
\hline \multirow{2}{*}{ Ханд ба бүлэг ханд } & \multicolumn{2}{|c|}{$Ц u$} & \multicolumn{3}{|c|}{ Яu } \\
\hline & гдх & үндэс & гдх & Үндэс & цэцэг \\
\hline Этанол & $345 \Gamma$ & 244 г & 720 г & 796 г & 392 г \\
\hline дХМ & 65.4 г & 46 г & 48.4 г & 110.3 г & 24 г \\
\hline$n-\mathrm{BuOH}$ & 116 г & $57.3 \Gamma$ & $425 \Gamma$ & $15.0 \Gamma$ & $219 \Gamma$ \\
\hline Усан үлдэгдэл & $26 \Gamma$ & 110 г & 219 г & 427.6 г & 89.7 г \\
\hline
\end{tabular}

Бодис ялгах, изээриүүлэх, тоо хэмжээг тодорхойлох, молекульн бүтэи байгууламжий тогтоох

Ци-н гдх-н 103.0 г $n$-ВuОН-н фракцыг 25-100 мкм жижиглэлттэй сефадекс $L H-20$ (Pharmacia, Uppsala, Sweden) шингээгчид шингээн, дихлорметан-метанол (1:1, $3: 1)$, метанол уусгагчийн системээр тус тус элюацалж 13 (I-XIII) фракц болгов. Эдгээр фракц тус бүрийг цаашид $L H-20$, 75-150 мкм жижиглэлттэй СНР 20Р гель (Mitsubishi Chemical Corporation, Japan), 4063 мкм жижиглэлттэй силикагель 60 (Merck, Darmstadt, Germany), 50 мкм жижиглэлттэй сепра C18-E шингээгчтэй баганан хроматографын аргаар нэрсэн ус, $10 \%$ метанол, 30\% метанол ба $60 \%$ метанолоос цэвэр метанол, түүнчлэн цэвэр этанолоос нэрсэн ус уусгагчийн системүүдээр элюацалж, 1 (14.9 мг), 2 (46.6 мг), 3 (936.6 мг), 4 (1.86 г), 5 (108.8 мг), 6 (1.42 г), 7 (436.4 мг) гэсэн гол нэгдлүүдийг цэврээр ялгав. Цэврээр ялгасан нэгдэл тус бүрийг тасалгааны температурт хатааж, тэдгээрийн тухайн түүхий эд дэх тоо хэмжээг жингийн анализын аргаар тодорхойлов.

Харин Ци-н үндэсний 57.0 г $n$-ВuОН-н фракцыг LH-20 шингээгчид шингээн, 80 $\%$ метанол, цэвэр метанол уусгагчийн системээр элюацалж 15 (I-XV) фракц болгов. Фракц тус бүрийг нимгэн үеийн хроматографын (HYX) аргаaр шинжилж цаашид сефадекс LH-20, CHP 20P гель, силикагель 60, сепра С18-Е шингээгчтэй баганан хроматографын аргаар хлороформметанол (19:1, 9:1, 6:1, 3:1), метанол, нэрсэн ус, $20 \%, 40 \%, 60 \%, 80 \%$ метанол, цэвэр метанол, түүнчлэн цэвэр этанолоос нэрсэн ус уусгагчийн системүүдээр элюацалж, 4 (2.11 г), 5 (0.5 г), 6 (3.21 г), 7 (5.5 г) гэсэн гол нэгдлүүдийг цэврээр ялгав.

Яй-н гдХ-н 100 г $n$-ВuОН-н фракцыг мөн сефадекс $L H-20$ шингээгчид шингээн, метанол, нэрсэн усаар элюацалж 19 (I-XIX) фракц болгож, цаашид сефадекс LH-20, СНР 20Р гель, силикагель 60, сепра С18 шингээгчтэй баганан хроматографын аргаар төрөл бүрийн уусгагчийн системүүдээр элюацалж, 1 (60.3 мг), 2 (57.9 мг), 3 (1.1 г), 4 (1.9 г), 5 (0.25 г), 6 (0.9 г), 7 (1.7 г) гэсэн гол нэгдлүүдийг цэврээр ялгав.

Яų-н цэцгийн 70 г $n$-ВuОН-н фракцыг сефадекс LH-20 шингээгчид шингээн, метанол, нэрсэн усаар элюацалж 10 (I-X) фракц болгож, цаашид сефадекс LH-20, СНР 20Р гель, силикагель 60, сепра С18 шингээгчтэй баганан хроматографын аргаар төрөл бүрийн уусгагчийн системүүдээр элюацалж, 1 (77.3 мг), 2 (58.7 мг), 3 (0.823 г), 4 (1.5 г), 5 (0.372 г), 6 (1.7 г), 7 (2.1 г) гэсэн гол нэгдлүүдийг цэврээр ялгав.

Харин Яи-н үндэсний 68.0 г $n$-ВuOH-н фракцыг сефадекс LH-20 шингээгчид шингээн, дихлорметан : метанол (3 : 1)-с цэвэр метанол уусгагчийн системээр элюацалж 10 (I-X) фракц авав. Эдгээр фракц тус бүрийг цэврээр ялгасан гол нэгдлүүдтэй харьцуулж $\mathrm{HYX}-\mathrm{H}$ аргаaр хлороформ : метанол : ус - 7: 3: 0.4, хлороформ : метанол - 9: 1 системд шалгаж, $1 \%$ ванилин, 5\% хүхрийн хүчил мөн 1\% дифенилборилэтиламин (NP), 5\% полиэтиленгликоль (PEG) урвалжуудаар тус тус үйлчилж үзэгдэх гэрэл ба хэт ягаан туяаны 254 нм болон 365 нм долгионы урттай гэрэлд шинжлэв. 
Ялгасан цэвэр нэгдлүүдийн молекулын бүтэц байгууламжийг нэг хэмжээст цөмийн соронзон резонансын (ЦСР) спектроскопын аргаар тодорхойлов. Бодисыг дейтерийн диметилсульфоксид (DMSO- $\left.d_{6}\right)$ болон метанолд $\left(\mathrm{CD}_{3} \mathrm{OD}-d_{4}\right)$ уусгаж ${ }^{1} \mathrm{H} \quad$ ба ${ }^{13}$ СЦСР спектрийг 270 ба 67 МГц-д JEOL JNM-EX270 FT-NMR спектрометрт тетраметилсилан дотоод стандарттай харьцуулан бүртгэсэн болно.

\section{СУДАЛГААНЫ ҮР ДҮН, ХЭЛЭЛЦЭМЖ}

Бид Цээнийн төрлийн Ци ба Яи гэсэн хоёр зүйл ургамлын гдх, цэцэг болон үндэсний химийн бүрэлдэхүүн найрлагыг нарийвчлан судалж тэдгээрт флавоноидын уламжлалын $1,2,3$, таннины төрлийн 4,5 , 6 болон монотерпений гликозид 7 нэгдлүүд зонхилдог болохыг тогтоов. Эмийн түүхий эд тус бүрээс цэврээр ялгасан нэгдлийн хэмжээг жингийн анализын аргаар тодорхойлж, улмаар агаарын хуурай дээжинд шилжүүлэн тооцоолж хувиар илэрхийлэн хүснэгт 2-т үзүүлэв.

ХУснэгт 2

Цээнийн төрлийн ургамльн эмийн түҮхий эд дэх гол нэгдлүүдийн хэмжээ

\begin{tabular}{ccccccc}
\hline \multirow{2}{*}{ Цэвэр нэгдэл } & \multicolumn{2}{c}{ Цц } & & \multicolumn{3}{c}{ Яц } \\
\cline { 2 - 3 } \cline { 5 - 6 } \cline { 5 - 6 } & гдх & үндэс & & гдх & үндэс & цэцэг \\
\hline $\mathbf{1}$ & $0.002 \%$ & - & & $0.025 \%$ & - & $0.016 \%$ \\
$\mathbf{3}$ & $0.005 \%$ & - & & $0.025 \%$ & - & $0.012 \%$ \\
$\mathbf{4}$ & $0.108 \%$ & - & & $0.467 \%$ & - & $0.171 \%$ \\
$\mathbf{5}$ & $0.216 \%$ & $0.211 \%$ & & $0.361 \%$ & $0.351 \%$ & $0.313 \%$ \\
$\mathbf{6}$ & $0.013 \%$ & $0.051 \%$ & & $0.107 \%$ & $0.082 \%$ & $0.077 \%$ \\
$\mathbf{7}$ & $0.165 \%$ & $0.321 \%$ & & $0.386 \%$ & $0.025 \%$ & $0.354 \%$ \\
\hline
\end{tabular}

Цэврээр ялгасан долоон нэгдлийн молекулын бүтэц байгууламжийг тэдгээрийн физик, химийн шинж чанар болон ЦСР-н спектроскопын аргуудаар судалж тогтоолоо.

Нэгдэл 1 нь шар өнгөтэй талст, НҮХ-д ХЯТ-ны 254 нм-т нил ягаан, NP/PEG үйлчлэхэд 366 нм-т улбар шар флуоресценцтэй. Метанолд сайн уусдаг. Мacc спектрийн шинжилгээгээр уг бодис $m / z$ : 302, $[\mathrm{M}+\mathrm{H}]^{+} \mathrm{C}_{15} \mathrm{H}_{10} \mathrm{O}_{7}$ молекул томьёотой болох нь тогтоогдов.

Энэ нэгдлийн ${ }^{1} \mathrm{H}$ ЦСР спектрт (300 МГц, DMSO- $\left.d_{6}\right) \delta, 6.16(1 \mathrm{H}, \mathrm{c}, \mathrm{H}-6), 6.39(1 \mathrm{H}, \mathrm{c}$, H-8), 6.88 (1Н, д, J=8.2 Гц, Н-5'), 7.53 (1Н, д, $J=7.8$ Гц, Н-6'), 7.66 (1Н, с, Н-2') 5 протоны дохио илрэв.

Харин ${ }^{13} \mathrm{C}$ ЦСР спектрт (125 МГц, DMSO- $\left.d_{6}\right) \delta, 146.78$ (C-2), 135.7 (C-3), 175.82 (C-4), 160.7 (C-5), 98.7 (C-6), 163.98 (C-7), 93.3 (C-8), 156.21 (C-9), 102.97 (C-
10), 121.93 (C-1'), 115.05 (C-2'), 145.04 (C-3'), 147.69 (C-4'), 115.58 (С-5'), 119.95 (C-6') 15 нүүрстөрөгчийн дохио тус тус илэрсэн ба эдгээр үр дүнг хэвлэлийн эх сурвалжтай харьцуулж 3, 5, 7, 3', 4'пентагидроксифлавон буюу кверцетин [12] гэж тодорхойлов (Зураг 1).

Кверцетин нь ургамлын аймагт элбэг тохиолддог метаболит бөгөөд исэлдэлтийн эсрэг хүчтэй үйлдэлтэй [13], бактер, вирусын эсрэг, үрэвсэл намдаах үйлдэлтэй [8] болох нь тогтоогджээ. Мөн хавдрын эсийн ургалтыг зогсоох, ДНХийн нийлэгжилтийг дарангуйлах зэрэг олон талт биологийн идэвхит нэгдэл юм [14]. Бидний судалгаагаар кверцетин нь $Я u$-н гдх-т их хэмжээтэй байгаа ба энэ нь Ци-н гдх-с 10 гаруй дахин их байна. Харин цэцгэнд $0.016 \%$ байв (Хүснэгт 2).

Нэгдэл 2 нь цайвар шар өнгөтэй талст, НҮХ-д ХЯТ-ны 254 нм-т нил 
ягаан, NP/PEG үйлчлэхэд 366 нм-т тод шар флуоресценцтэй. Метанолд сайн уусдаг. Масс спектрийн шинжилгээгээр уг бодис $m / z$ : 287, $[\mathrm{M}+\mathrm{H}]^{+} \mathrm{C}_{15} \mathrm{H}_{10} \mathrm{O}_{6}$ молекул томьёотой болохыг тогтоов.

${ }^{1} \mathrm{H}$ ЦСР спектрт (300 МГц, DMSO- $d_{6}$ ) $\delta$, 6.17 (1H, д, $J=1.35, \mathrm{H}-6), 6.42$ (1H, д, $J=1.16$ Н-8), 6.92 (2Н, д, J=8.79 Гц, Н-3' ба Н-5'), 8.04 (2Н, д, J=8.79 Гц, Н-2' ба Н-6') гэсэн 6 протоны дохио илрэв.

Харин ${ }^{13} \mathrm{C}$ ЦСР спектрт (125 МГц, DMSO- $\left.d_{6}\right) \delta, 156.13$ (C-2), 135.62 (C-3), 175.87 (C-4), 160.67 (C-5), 98.16 (C-6), 163.85 (C-7), 93.43 (C-8), 159.15 (C-9), 103.0 (C-10), 121.62 (C-1'), 129.45 (C-2', C-6'), 115.4 (С-3' ба С-5'), 146.77 (C-4') гэсэн 15 нүүрстөрөгчийн дохио тус тус илрэв. Энэ нэгдлийн физик, химийн шинж чанар болон спектрийн шинжилгээний дүнг хэвлэлийн эх сурвалжтай харьцуулан баталгаажуулж, 3,5,7,4'-тетрагидроксифлавон буюу кемпферол [15] гэж тодорхойлов (Зураг 1).

Кемпферол нь мөн ургамлын аймагт өргөн тархсан бөгөөд үрэвслийн эсрэг, зүрх судасны өвчнөөс сэргийлэх, цитотоксик, апоптозын процессыг өдөөж хавдрын эсийг устгах үйлдэлтэй нэгдэл юм [16]. Бидний судалгаагаар кемпферол нь Яй-н гдХ-т хамгийн их буюу $0.025 \%$, цэцгэнд түүнээс 2 дахин, Цич-н гдх-т 5 дахин бага хэмжээтэй агуулагдаж байна (Хүснэгт 2).

Флавоноидын уламжлалын дээрх хоёр нэгдэл нь тухайн зүйл ургамлуудын эмийн түүхий эдэд ихэвчлэн гликозид байдлаар байгаа нь судалгааны явцад ажиглагдаж байв.

Нэгдэл 3 нь цайвар шар өнгөтэй талст, НҮХ-д ХЯТ-ны 254 нм-т нил ягаан, NP/PEG үйлчлэхэд 366 нм-т тод шар флуоресценцтэй. Метанолд сайн уусдаг, хлороформд уусдаггүй. Масс спектрийн шинжилгээгээр уг бодис $m / z: 448,[\mathrm{M}+\mathrm{H}]^{+}$ $\mathrm{C}_{21} \mathrm{H}_{20} \mathrm{O}_{11}$ молекул томьёотой болох нь тогтоогдов.

${ }^{1} \mathrm{H}$ ЦСР спектрт (500 МГц, DMSO- $\left.d_{6}\right)$ $\delta, 12.62$ (c, OH (C-5)), 10.35 (c, OH (C-7)), $6.20(1 \mathrm{H}$, д, $J=2$ Гц, Н-6), $6.40(1 \mathrm{H}$, д, $J=2$
Гц, Н-8), 6.87 (2Н, д, J=9.0 Гц, Н-3', Н-5'), 8.03 (2Н, д, J=8.5 Гц, Н-2', Н-6'), 5.46 (1Н, д, $J=7.5$ Гц, сахарын аномер Н-1"), 3.553.14 (5Н, м, Н-2”, Н-3”, Н-4”, Н-5”, Н-6”) протоны дохио тус тус илрэв.

Харин ${ }^{13} \mathrm{C}$ спектрт ЦСР (125 МГц, DMSO- $\left.d_{6}\right) \delta, 156.39$ (C-2), 133.17 (C-3), 177.43 (C-4), 161.21 (C-5), 98.73 (C-6), 164.33 (C-7), 93.66 (C-8), 156.20 (C-9), 103.93 (C-10), 120.90 (C-1'), 130.87 (C-2', C-6'), 115.09 (C-3', C-5'), 159.94 (C-4'), 100.87 (C-1"), 74.21 (C-2”), 77.49 (C-3"), 69.89 (С-4”), 76.42 (С-5”), 60.83 (С-6") гэсэн 21 нүүрстөрөгчийн дохио тус тус илэрлээ.

Энэ нэгдлийн физик, химийн шинж чанар болон спектрийн шинжилгээний дүнг хэвлэлийн эх сурвалжтай харьцуулан баталгаажуулж, кемпферол-3-O- $\beta$-Dглюкопиранозид буюу астрагалин гэж таньж тодорхойлов (Зураг 1). Катіуа К. нар энэ нэгдлийг Ци-н каллусын өсгөврөөс ялгаж молекулын бүтцийг тогтоосон байдаг [17].

Астрагалин нь үрэвслийг дарах, ясны сийрэгжилтийн эсрэг, үл исэлдүүлэх, тирозиназа ферментийг дарангуйлах үйлдэлтэй болох нь тогтоогджээ [18-19]. Флавоноидын уламжлалын нэгдлүүдээс астрагалин дээрх хоёр зүйл ургамлын гдх-т зонхилж байгаа ба ялангуяа $Я u$-д хамгийн их хэмжээтэй байв (Хүснэгт 2).

Нэгдэл 4 нь цагаан өнгөтэй талст, НYХ-д ХЯТ-ны 254 нм-т нил ягаан, NP/PEG үйлчлэхэд 366 нм-т тод хөх флуоресценцтэй, $5 \% \mathrm{H}_{2} \mathrm{SO}_{4}$-р үйлчлэхэд хүрэн улаан өнгөтэй болдог. Метанолд сайн, хлороформд муу уусдаг. Масс спектрийн шинжилгээгээр уг нэгдэл $m / z: 198,[\mathrm{M}+\mathrm{H}]^{+} \mathrm{C}_{9} \mathrm{H}_{10} \mathrm{O}_{5}$ молекул томьёотой болох нь тогтоогдов.

${ }^{13} \mathrm{C}\left(125 \mathrm{MГц,} \mathrm{CD}_{3} \mathrm{OD}\right)$ ба ${ }^{1} \mathrm{H}(500 \mathrm{MГц,}$ $\left.\mathrm{CD}_{3} \mathrm{OD}, \delta\right)$ ЦCР спектрийн үзүүлэлтүүдийг (Хүснэгт 3) хэвлэлийн эх сурвалжтай харьцуулан баталгаажуулж, мөн физик, химийн шинж чанарт нь тулгуурлан энэ нэгдлийг этил-3,4,5-тригидрокси-бензойны хүчил буюу этилгаллат [20] гэж таньж тодорхойлов (Зураг 1). 
УГ нэгдэл нь апоптозын процессыг өдөөх, цитотоксик үйлдэлтэй болох нь тогтоогджээ [21]. Этилгаллат нь Яи-н эмийн түүхий эдүүдэд ойролцоо буюу $0.313 \%$ $0.361 \%$ байгаа бол Ци-д тэдгээрээс 1.5-1.6 дахин бага хэмжээтэй байна (Хүснэгт 2).

Нэгдэл 5 нь цагаан өнгөтэй аморф, НҮХ-д ХЯТ-ны 254 нм-т нил ягаан, NP/PEG үйлчлэхэд 366 нм-т тод хөх флуоресценцтэй, 5 \% $\mathrm{H}_{2} \mathrm{SO}_{4}$-р үйлчлэхэд хүрэн улаан өнгөтэй болдог. Метанолд сайн уусдаг, харин хлороформд уусдаггүй. Масс спектрийн шинжилгээгээр $m / z: 170$, $[\mathrm{M}+\mathrm{H}]^{+} \mathrm{C}_{8} \mathrm{H}_{8} \mathrm{O}_{5}$ молекул томьёотой болох нь тогтоогдов.

${ }^{1} \mathrm{H}$ ЦСР спектрт (500 МГц, DMSO- $\left.d_{6}\right) \delta$, 6.92 ба $6.94(1 \mathrm{H}, \mathrm{c}, \mathrm{H}-2, \mathrm{H}-6), 9.48(3 \mathrm{H}, \mathrm{c}$, $(\mathrm{OH}))$ дохио илрэв. ${ }^{13} \mathrm{C}$ ЦСР спектрт $(125$ МГц, DMSO- $\left.d_{6}\right) \delta, 120.65(\mathrm{C}-1), 108.93(\mathrm{C}-$ 2, C-6), 145.59 (C-3, C-5), 138.17 (C-4), 167.69 (С-7) 7 нүүрстөрөгчийн дохио тус тус илэрлээ. Эдгээр үр дүнг хэвлэлийн эх сурвалжтай харьцуулан баталгаажуулж энэ нэгдлийг 3,4,5-тригидроксибензойны хүчил буюу галлын хүчил гэж тодорхойлов (Зураг 1). Энэ нэгдлийг Ци ургамлын үндэснээс Lee S.Ch нар ялгаж DPPH чөлөөт язгуурыг зайлуулах ба липидийн хэт исэлдэлтийг дарангуйлах үйлдэлтэй болохыг тогтоожээ [22]. Галлын хүчил нь Яи-н гдх, цэцгэнд их байгаа ба Ци-н гдх-т түүнээс 10 дахин бага байна. Харин энэ нэгдэл нь дээрх хоёр зүйл ургамлын үндсэнд ойролцоо хэмжээтэй байв (Хүснэгт 2).

Нэгдэл 6 нь цагаан өнгөтэй талст бодис, ХЯТ-ны 254 нм-т нил ягаан, NP/PEG үйлчлэхэд 366 нм-т тод хөх флуоресценцтэй. $5 \% \mathrm{H}_{2} \mathrm{SO}_{4}$-p үйлчлэхэд хүрэн улаан өнгөтэй болдог. Этанолд сайн уусдаг. Масс спектрийн шинжилгээгээр уг бодис $m / z$ : 941, [M+H] $]^{+} \mathrm{C}_{41} \mathrm{H}_{32} \mathrm{O}_{26}$ молекул томьёотой болох нь тогтоогдов.

Энэ нэгдлийн ${ }^{13} \mathrm{C}\left(125 \mathrm{MГц,} \mathrm{CD}_{3} \mathrm{OD}\right)$ ба ${ }^{1} \mathrm{H}\left(500\right.$ МГц, $\left.\mathrm{CD}_{3} \mathrm{OD}, \delta\right)$ спектрийн үзүүлэлтүүдийг (Хүснэгт 3) хэвлэлийн эх сурвалжтай харьцуулан баталгаажуулж, мөн физик, химийн шинж чанарт нь тулгуурлан 1, 2, 3, 4, 6 - пентагаллоил - О $\beta$ - D - глюкопираноз [23] гэж тодорхойлсон ба Ци-н үндэснээс Nishizawa M. нар ялгаж бүтцийг тогтоосон байдаг [24].

Энэ нь Цээнийн төрлийн ургамалд зонхилох гол нэгдэл бөгөөд P.suffruticosa, P.moutan, P.lactiflora ургамлуудаaс ялгаж, элэгний хавдрын SK-Hер 1 эсийн ургалтыг дарангуйлах, эс дотор үүссэн чөлөөт язгуурыг зайлуулах, үрэвслийг дарах, холестеролын нийлэгжилтэнд голлох Үүрэгтэй скваленсинтетаза ферментийг дарангуйлах, элэгний $\mathrm{B}$ вирусын эсрэг зэрэг олон талын биологийн үйлдэлтэй болохыг судлан тогтоожээ [25-28]. Бидний судалгаагаар энэ нэгдэл нь $Я u$-н гдх ба цэцгэнд зонхилж байгаa ба Ци-н гдх-с 2 дахин их байв. Харин Ци-н үндсэнд гдх-сээ 2.0 дахин их буюу $0.321 \%$ байлаа.

Нэгдэл 7 нь цайвар өнгөтэй талст, 1 \% ванилин ба $5 \% \mathrm{H}_{2} \mathrm{SO}_{4}$-p дараалуулан үйлчлэхэд нил ягаан өнгөтэй ба метанол, ацетонд сайн уусдаг, хлороформд уусдаггүй. Масс спектрийн шинжилгээгээр $m / z: 480$, $[\mathrm{M}+\mathrm{H}]^{+} \mathrm{C}_{23} \mathrm{H}_{28} \mathrm{O}_{11}$ молекул томъёотой болох нь тогтоогдов.

${ }^{1} \mathrm{H}$ ЦСР спектрт (DMSO-d $) \delta, 1.36(3 \mathrm{H}$, c, $\left.-\mathrm{CH}_{3}\right), 2.21$ (1H, д, $J=12.5$ Гц, Н-3a), 1.83 $(1 \mathrm{H}$, д, $J=12.5$ Гц, Н-3b), 2.59 (1Н, д, $J=6$ Гц, Н-5), 2.52 (1Н, дд, $J=10.83$ Гц, Н-7a), 1.97 (1H, д, $J=10.7$ Гц, Н-7b), 4.74 (2H, с, H-8), 5.42 (1H, с, H-9), 4.54 (1Н, д, $J=7.5$ Гц, Н-1'), 3.21 - 3.35 (4H, м, Н-2', Н-4', H-3', H-5'), 3.87 (1H, d, J=11.8 Гц, Н-6'a), 3.64 (1Н, дд, $J=11.91$ Гц, Н-6’b), 8.04 (1Н, д, $J=7.11$ Гц, Н-2"), 7.51 (2Н, т, J=7.4 Гц, Н-3” ба Н-5”), 7.64 (1Н, т, J=7.4 Гц, Н-4”), 8.09 (1Н, д, J=7.11 Гц, Н-6") протоны дохио тус тус илрэв.

Харин ${ }^{13} \mathrm{C}$ ЦСР спектрт (DMSO- $\left.d_{6}\right) \delta$, 89.35 (C-1), 87.25 (C-2), 44.54 (C-3), 106.39 (C-4), 43.97 (C-5), 72.24 (C-6), 23.42 (C7), 61.71 (C-8), 102.31 (C-9), 19.60 (C-10), 100.19(C-1'), 75.02 (C-2'), 78.06 (C-3'), 71.75 (C-4'), 77.97 (C-5'), 62.88 (C-6'), 131.22 (C1"), 130.68 (C-2" ба С-6"), 129.64 (С-3" ба C-5”), 134.42 (С-4"), 167.98 (С-7”) гэсэн 
23 нүүрстөрөгчийн дохио тус тус илэрсэн ба эдгээр үр дүнг хэвлэлийн эх сурвалжтай харьцуулан баталгаажуулж, уг нэгдлийг Цээнийн төрлийн ургамалд зонхилон агуулагддаг монотерпений гликозид болох паеонифлорин гэж тодорхойлов [29] (Зураг $1)$.

ХУснэгт 3

4 ба 6 нэгдлийн ${ }^{1} Н$ болон ${ }^{13} \mathrm{C} \mathrm{ЦСР-н} \mathrm{спектрийн} \mathrm{харьиуулсан} \mathrm{үзуүлэлт}$

\begin{tabular}{|c|c|c|c|c|}
\hline \multirow{2}{*}{ Нүүрстөрөгч } & \multicolumn{2}{|r|}{4} & \multicolumn{2}{|r|}{6} \\
\hline & $\boldsymbol{\delta}_{c}$ & $\boldsymbol{\delta}_{\mathrm{H}}$ & $\boldsymbol{\delta}_{\mathcal{C}}$ & $\boldsymbol{\delta}_{\mathrm{H}}$ \\
\hline \multirow[t]{5}{*}{ C-7 } & 165.8 & - & 167.91 & - \\
\hline & & & 167.28 & \\
\hline & & & 167.00 & \\
\hline & & & 166.91 & \\
\hline & & & 166.21 & \\
\hline \multirow[t]{5}{*}{$\mathrm{C}-3, \mathrm{C}-5$} & 145.54 & - & 146.54 & \\
\hline & & & 146.45 & \\
\hline & & & 146.42 & \\
\hline & & & 146.36 & \\
\hline & & & 146.26 & \\
\hline \multirow[t]{4}{*}{$\mathrm{C}-4$} & 138.32 & & 140.77 & \\
\hline & & & 140.36 & \\
\hline & & & 140.21 & \\
\hline & & & 140.00 & \\
\hline \multirow[t]{4}{*}{$\mathrm{C}-1$} & 119.56 & - & 121.02 & - \\
\hline & & & 120.33 & \\
\hline & & & 120.17 & \\
\hline & & & 119.69 & \\
\hline \multirow[t]{3}{*}{ C-2, C-6 } & 108.45 & $6.94(2 \mathrm{H}, \mathrm{c})$ & 110.60 & $6.87-7.15$ \\
\hline & & & 110.39 & \\
\hline & & & 110.32 & $(10 \mathrm{H}, 5 \mathrm{c})$ \\
\hline$-\mathrm{CH}_{2}-$ & 59.96 & $4.19(2 \mathrm{H}$, к, $J=7.0$ Гц $)$ & - & - \\
\hline $\mathrm{CH}_{3}^{-}$ & 1424 & $1.27(3 \mathrm{H}, \mathrm{t}, J=7.0$ Гц $)$ & - & - \\
\hline C- 1 & & & 93.81 & $6.25(1 \mathrm{H}$, д, $J=8.28$ Гц $)$ \\
\hline C- $2^{\prime}$ & & & 72.19 & $5.62(1 \mathrm{H}, \kappa, J=8.64$ Гц $)$ \\
\hline C- 3 , & & & 74.09 & $5.94(1 \mathrm{H}, \mathrm{T}, J=9.63$ Гц $)$ \\
\hline C- 4' & & & 69.78 & $5.62(1 \mathrm{H}, \kappa, J=8.64$ Гц $)$ \\
\hline C- 5 , & & & 74.39 & $4.54(1 \mathrm{H}, \mathrm{m})$ \\
\hline C- $6^{\prime}$ & & & 63.10 & $4.42(1 \mathrm{H}, \mathrm{m})$ \\
\hline
\end{tabular}

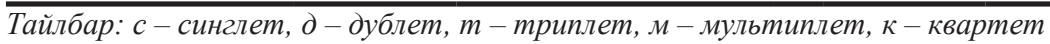

Энэ нэгдэл нь эсийн дотор болон гадна Үүссэн чөлөөт язгуурыг шууд бус замаар зайлуулах, мэдрэлийн эсийг хамгаалах, холестеролын хэмжээг бууруулах зэрэг үйлдэлтэй болох нь тогтоогджээ [30-32]. Паеонифлорин нь Ци ба Яй-н үндсэнд ойролцоо хэмжээтэй байсан бол Яu--н гдх-т Ци-с 13 дахин их байна (Хүснэгт 2).
Цээнийн зүйл ургамлуудын эмийн түүхий эдэд эдгээр нэгдэл нь зонхилон агуулагдаж байгаa ба ялануяа нэгдэл 1-г Ци болон Яu-с, нэгдэл 3-г Яų-н гдх-с анх удаа ялгалаа.

Энгийн фенол, таннины төрлийн нэгдлүүд болон монотерпений гликозид нь Цээнийн төрлийн дээрх хоёр зүйл ургамлын 
эмийн түүхий эдэд зонхилж байна. Харин флавоноидын уламжлалын нэгдэл нь бусад ангиллын нэгдлээс бага хэмжээтэй боловч гдХ-т зонхилж байна.

Бид Ци-н гдх-н химийн судалгааг анх удаа хийж түүнд флавоноидын уламжлалын нэгдэл $\mathbf{3}$, энгийн фенолын уламжлалын нэгдэл 4, таннины ангиллын нэгдэл 6 зонхилж байгааг тогтоолоо. Харин үндэсний химийн бүрэлдэхүүн найрлагыг хятад, солонгос, японы эрдэмтэд судалж түүнд монотерпений гликозид, таннины төрлийн нэгдлүүд зонхилдог болохыг тогтоосон байдаг [5-7] бөгөөд үүнтэй бидний судалгааны дүн тохирч байна.

Яи ургамлын химийн бүрэлдэхүүн найрлага нь Цээнийн төрлийн бусад зүйлтэй харьцуулахад бага судлагдсан ба үндэсний гадна хальсанд тритерпен, монотерпений гликозидууд, жимсэнд флавоноид, таннины уламжлалын нэгдлүүд, үндсэнд монотерпений гликозид зонхилж байгааг тогтоосон байдаг [33-35].<smiles>[R]c1cc(-c2oc3cc(O)cc(O)c3c(=O)c2[R20])ccc1Cl</smiles>

\begin{tabular}{ccc}
\cline { 2 - 3 } & $\mathbf{R}_{1}$ & $\mathbf{R}_{2}$ \\
\cline { 2 - 3 } 2 & - OH & $-H$ \\
2 & $-H$ & $-H$ \\
3 & $-H$ & $\boldsymbol{\beta}$-D mокопииранозмд
\end{tabular}<smiles>O=C(O)c1cc(O)c(O)c(O)c1</smiles>

5

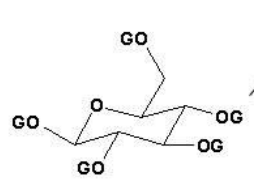

6<smiles>CCOC(=O)c1cc(O)c(O)c(O)c1</smiles>

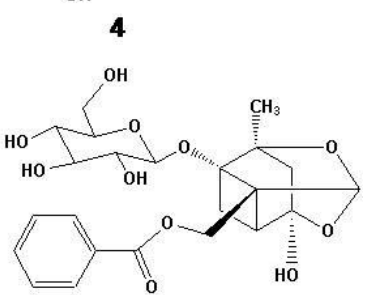

7

Зураг 1. Цээнийн төрлийн ургамал дахь гол нэгдлҮҮд

Харин бид Яй-н цэцэг, гдх-н химийн найрлага, бүрэлдэхүүнийг анх удаa судалсны дүнд тэдгээрт флавоноидын уламжлалын нэгдэл $\mathbf{1 ,} 2$ болон түүний гликозидууд, энгийн фенол, таннины төрлийн нэгдлүүд зонхилж байгаа ба эдгээр нь гдх-т их хэмжээтэй байгааг

\section{ДҮГНЭЛТ}

Монгол оронд ургадаг Цээнийн төрлийн Цагаан изэнэ (Paeonia lactiflora Pall.) ба Ягаан изээнэ (Paeonia anomala L.)-н газрын дээд хэсэг, цэцэг, үндэсний химийн бүрэлдэхүүн, найрлагыг нарийвчлан судалсны дүнд энэ хоёр зүйл ургамал нь химийн бүрэлдэхүүнээрээ хоорондоо төсөөтэй ба биологийн идэвхт гол нэгдлүүд тогтоов. Яu-н үндсэнд Ци-ийхтэй мөн адил флавоноидын уламжлалын нэгдэл илрээгүй ба монотерпений гликозид 7 , энгийн фенолын ангиллын нэгдэл 4, 5 зонхилж байна. Түүнчлэн таннины уламжлалын нэгдэл нь үндсэнд илүҮ хэмжээтэй байгаа нь ажиглагдлаа.

ч ижил байна. Гэхдээ Ягаан иэээнийн эмийн түүхий эд дэх биологийн идэвхит гол нэгдлүүд нь Цагаан изээнийхээс их хэмжээтэй байна.

Цээнийн төрлийн дээрх хоёр зүйлийн химийн бүрэлдэхүүн, найрлагыг харьцуулан судалсан ажил урьд өмнө байгаагүй тул тэдгээрт зонхилон агуулагддаг биологийн $-98-$ 
идэвхт нэгдлүүдийн тоо хэмжээг эмийн түүхий эд тус бүрт нь анх тодорхойлсон нь шинжлэх ухааны шинэ мэдээлэл болж байна. Энэ нь эдгээр ургамлын ямар эд, эрхтэнг эм, хүнс, гоо сайхны бүтээгдэхүүний түүхий эд болгон ашиглаж болохыг илэрхийлж буй үнэ цэнэтэй суурь мэдээлэл болохын зэрэгцээ практик ач холбогдолтой юм.

\section{Талархал}

Цэвэр нэгдлүүдийн ЦСР-н спектрийг бичсэн Өвөр монголын Их сургуулийн Монгол эм, химийн хүрээлэнгийн профессор Б.Гэрэлт болон докторант Б.Мөнхөө нарт талархал илэрхийлье.

\section{Ашигласан бүтээлийн жагсаалт}

1. Editorial committee of the administration bureau of Chinese flora, 'Chinese Flora' science Press, Beijing, 1979, 27, 37.

2. Грубов В.И., Определить сосудистых растений Монголии, Ленинград, Наука, 1982, 129-130.

3. Болдсайхан Б., Монгол орны эмийн ургамльнн нэвтэрхий толь, УБ, 2004, 61-62.

4. Лигаа У., Даваасүрэн Б., Монгол орны эмийн ургамльг өрнө дорны анагаах ухаанд хэрэглэхүй, Bayn mongol capital, УБ, 2005, 480-482.

5. Muracami N., Saka M., Shimada H., Matsuda H., Yamahara J., Yoshikawa M., New bioactive monoterpene glucoside from Paeonia radix, Chem.Pharm.Bull, 1996, 44, 1279-1278.

6. Guo D., Ye G., Guo H., A new phenolic glucosides from Paeonia lactiflora, Fitoter, 2006, 77, 613.

7. Ulubelen A., Wagner H., Isolation of quercetin-3-O-galacto-7-rhamnoside and kaempferol digalactoside from the leaves of Paeonia decora, Z.Natursch, 1970, 25, 114.

8. Harbone J.B., Williams C., Advances in flavonoid research since 1992. Phytochemistry, 2000, 55, 481-504.

9. Spencer J.P., Abd El Mohsen M.M., Minihane A.M., Mathers J.C., Biomarkers of the intake of dietary polyphenols: strengths, limitations and application in nutrition research, Br.J.Nutr, 2008, 99, 12-22.

10. Middleton E., Kandaswami Ch., Theoharides Th.C., The effect of plant flavonoids on mammalian cells: implications for inflammation, heart disease and cancer, Pharmacol.Rev, 2000, 52, 673-751.

11. Quideau S., Deffieux D., Douat-Casassus C., Pouysegu L., Plant polyphenols: chemical properties, biological activities, and synthesis, Angew.Chem.Int.Ed.Engl., 2011, 50, 586621.

12. Malgorzata M., Quercetin and its derivatives: Chemical structure and bioactivity-A review, J.Food.Nutr.Sci, 2008, 58(4), 407-413.

13. Prior R.L., Fruits and vegetables in the prevention of cellular oxidative damage, Am.J.Clin. Nutr, 2003, 78, 570-578.

14. Erkoc S., Erkoc F., Keskin N., Theoretical investigation of quercetin and its radical isomers, J.Mol.Struct, 2003, 631, 141-146.

15. Chunpeng W., Yanying Y., Shuwen C., Isolation and identification of phenolic compounds from Gynura divaricata leaves, Pharmacogn.Mag, 2011, 7(26), 101-108.

16. Yoshida T., Konishi M., Horinaka M., Yasuda T., Goda A.E., Taniguchi H., Yano K., Wakada M., Sakai T., Kaempferol sensitizes colon cancer cells to TRAIL-induced apoptosis, Biochem. Biophys.Res.Comm, 2008, 375, 129-133.

17. Kamiya K., Youshioka K., Ikuta A., Satake T., Triterpenoids and flavonoids from Paeonia lactiflora Pall, Phytochem, 1994, 44, 141-144.

18. Kim M.S., Kim S.H., Inhibitory effect of astragalin on expression of lipopolysaccharide- 
induced inflammatory mediators through NF-țB in macrophages, Arch.Pharm.Res, 2011, 34, 2101-2107.

19. Xue Y.L., Miyakawa T., Hayashi Y., Okamoto K., Hu F., Mitani N., Furihata K., Sawano Y., Isolation and tyrosinase inhibitory effects of polyphenols from the leaves of persimmon, Diospyros kaki, J.Agric.Food.Chem, 2011, 59, 6011-6017.

20. Sato Y., Oketani H., Singyouchi K., Otsubo T., Kihara M., Shibata H., Higuti T., Extraction and purification of effective constituents of Terminalia chebula Rets against MethicilinResistant Staphylococcus aureus, Biol Pharm.Bull, 1997, 20(4), 401-404.

21. Kim W.H., Song H.O., Park H., Ethyl gallate induces apoptosis of HL-60 cells by promoting the expression of caspases-8,-9,-3-apoptosis-inducing factor and endonuclease G, Int.J.Mol. Sci, 2012, 13(9), 11912-22.

22. Lee S.Ch., Kwon Y.S., Kyung H.S., Moon Y.H., Antioxidative constituents from Paeonia lactiflora Pall., Arch.Pharm.Res, 2005, 28, 775-783.

23. Cho J.Y., Sohn M.J., Lee J.K, Kim W.G., Isolation and identification of pentagalloyl glucose with broad spectrum antibacterial activity from Rhustrichocarpa miquel, Food.Chem, 2010, 123, 501-506.

24. Nishizawa M., Yamagishi T., Tannins and related compounds Part 5. Isolation and characterization of polygalloyl glucose from Chinese gallotannin, J.Soc.Perkin.Trans. 1983, I, 2963-2968.

25. Oh G.S., Pae H.O., Oh H., In vitro anti-proliferative effect of 1,2,3,4,6-penta-O-galloylbeta-D-glucose on human hepatocellular carcinoma cell line, SK-HEP-1 cells, Cancer.Lett, 2001, 174(1), 17-24.

26. Choi B.M., Kim H.J., Oh G.S., 1,2,3,4,6-Penta-O-galloyl-beta-D-glucose protects rat neuronal cells (Neuro 2A) from hydrogen peroxide-mediated cell death via the induction of heme oxygenase-1, Neurosci.Lett, 2002, 328(2), 185-189.

27. Park J.K, Cho H.J., Lim Y., Cho Y.H., Lee C.H., Hypocholestrolemic effect of CJ90002 in hamsters: A potent inhibitor for squalene synthase from Paeonia moutan, Jour.Microbio. Biotech, 2002, 12(2), 222-227.

28. Lee S.J., Lee H.K., Jung M.K., Mar W., In vitro antiviral activity of 1,2,3,4,6-penta-O-galloylbeta-D-glucose against hepatitis B virus, Biol.Pharm.Bull, 2006, 29(10), 2131-2134.

29. Aimi N., Inaba M., Watanabe M., Shibata S., Paeoniflorin glucoside of Chinese peony root, Tetrahedron, 1969, 25(9), 1825-1838.

30. Ryu G., Park E.K., Joo J.H., Lee B.H., Choi B.W., Jung D.S., Lee N.H., A new antioxidant monoterpene glycoside, alpha-benzoyloxypaeoniflorin from Paeonia suffruticosa, Arch. Pharm.Res, 2001, 24, 105-108.

31. Peng Li., Zhao H.L., Neuroprotective effect of paeoniflorin on $\mathrm{H}_{2} \mathrm{O}_{2}$-induced apoptosis in PC12 cells by modulation of reactive oxygen species and the inflammatory response, Exp. Ther.Med, 2015, 9, 1768-1772.

32. Yang H., Ko W.K., Kim J.Y., Ro H.S., Paeoniflorin: an antihyperlipidemic agent from Paeonia lactiflora, Fitoterapia, 2004, 75, 45-9.

33. Xian L., Sheng L., Jian-Xin P., Shen-Xiong H., Chemical constituents from Paeonia anomala subsp. Veitchii (Paeoniaceae), Acta.Botanic.Yunn, 2007, 29, 259-262.

34. Sarangerel O., Kim Ch.Y., Kang K., Batsuren D., Tunsag J., Nho Ch.W., Protective effect of Paeonia anomala extract and constituents against tert-butylhydro-peroxide-induced oxidative stress in HepG2 cells, Planta.Med, 2013, 79, 116-1226.

35. Осадчий С.А., Черняк И.Е., Шакиров М.М., Шульи Э.Э., Толстиков Г.А., Корни пиона уклоняющегося (Paeonia anomala L.) сибирской популяиии как источник гликозидов паеонифлорина и пеоновицианозида, Химия в интересах устойчивого развития, 2000, 8, 399-403. 


\title{
MAJOR COMPOUNDS OF THE PAEONIA GENUS
}

\author{
E.Purevdorj, G.Odontuya \\ Natural Product Chemistry Laboratory, Institute of Chemistry and Chemical Technology, MAS \\ E-mail: g.odontuya@hotmail.com
}

\begin{abstract}
For the first time a comparative study on chemical composition of aerial parts, flowers and roots of Paeonia lactiflora Pall. and Paeonia anomala L. growing in Mongolia has been performed. According to the study quercetin (1), kaempferol (2), kaempferol-3-O- $\beta$-D-glucopyranoside (3) ethylgallate (4), gallic acid (5), 1,2,3,4,6-pentagalloyl-O- $\beta$-D-glucopyranoside (6) and paeoniflorin (7) have been isolated and determined as a major components. Molecular structures of isolated components were identified on the basis of their physico-chemical characteristics and by using nuclear magnetic resonances spectroscopic methods. Compound $\mathbf{1}$ was isolated from both species, while compound $\mathbf{3}$ was isolated from P.anomala for the first time.

During the isolation and purification procedure the high amount of phenolics (4 and 5), tannin (6) and monoterpene glycoside (7) had been yielded and determined in all crude drugs, while flavonoid derivatives $(\mathbf{1}, \mathbf{2}$ and $\mathbf{3}$ ) were in the less amount in comparison to other classes of compounds. However, flavonoid derivatives were found mainly in the aerial parts of both species, while they were not detected in the roots. The aerial parts of P.lactiflora were rich in compounds $3(0.108 \%), 4(0.216 \%)$ and $6(0.165 \%)$, while the compounds $4(0.361 \%), 6(0.386 \%)$ and 7 $(0.725 \%)$ were found as the main in P.anomala. In addition, these compounds had been detected as a major one in flowers of P.anomala. Roots of both plant species were rich in compounds 4 and 7.

Previously, there was not carried out any comparative investigation of chemical composition in these two species of Paeonia growing in Mongolia. The determination of biological active main components in percentages in each crude drug of both species of Paeonia can be considered a new infiormation in scientific knowledge. Thus, these results can be a valuable basic statement to guide that which part of these plants could be use as a medicinal, food and cosmetic raw materials. This is could be the main practical significance of this work.
\end{abstract}

Keywords: Paeonia lactiflora, Paeonia anomala, biological active compounds, molecular structure, amount 